The present investigations will be published in full elsewhere.

$$
\begin{gathered}
\text { Department of Histology, } \\
\text { Karolinska Institutet, } \\
\text { Stockholm } 60 . \\
\text { Dec. } 18 .
\end{gathered}
$$

\section{LARS GyLLENSTEN}

${ }^{2}$ Kinsey, V. L., Jacobus, J. T., and Hemphill, F. M., A.M.A. Arch. Ophthalmol., 56, 481 (1956)

2Gyllensten, L., and Hellström, B., Acta Paediat., 43, Supp. 100, 131 (1954).

"Ashton, N., Ward, B., and Serpell, G., Brit. J. Opht almol., 38, 397 (1954).

' Patz, A., Amer. J. Ophthalmol., 38, 291 (1954).

s Berfenstan, R., Edlund, T., and Zettergren, L., Acta Paediat., 47, 82

(1958).
'Williams, C. E., Brit. J. Ophthalmol., 42, 549 (1958). 'Ashton, N., Graymore, C., and Pedler, Ch., Brit. J. Ophthalmol., 41,

\section{Role of the Thymus in Murine Leukæmia}

LYMPносXTIC neoplasms with characteristic thymic involvement occur spontaneously with high frequency in certain strains of mice $\theta^{1}$, and in other strains following $\mathrm{X}$-irradiation ${ }^{2}$, chemical carcinogens ${ }^{3}$ or the inoculation at birth of cell-free extracts of leukæmic tissue from high leukæmic strain mice ${ }^{4}$. Total thymectomy has been shown to reduce markedly the incidence of the disease, either spontaneous ${ }^{1}$ or induced $^{2,3}$. No report has yet appeared as to the effect of subsequent thymectomy on the occurrence of the disease in mice inoculated at birth with leukæmia extracts. Harris ${ }^{5}$ has, however, an interesting theory which suggests that non-cellular leukæmicinducing extracts might be capable of replacing thymic influence. Latarjet et al. ${ }^{6}$ and Furth et al. ${ }^{7}$ have shown that inoculation of $A k$ leukæmic cell-free extracts into newborn $A k$ mice accelerates the development of leukæmia. The effect of thymectomy on this acceleration has been investigated and reported here.

Newborn $A k_{i}$ mice, from a colony maintained by strict sib-matings in these laboratories since 1945, were divided into three approximately equal groups, each litter being divided between the three groups. The control group had their tails cut off for identification purposes but received no further treatment apart from an intraperitoneal injection of saline. Mice in the other two groups were inoculated within $16 \mathrm{hr}$. of birth with $A k_{i}$ leukæmic cell-free filtrates prepared according to Gross's method4. Extracts were made from either leukæmic thymus only, or leukæmic lymph nodes only. At 3-4 weeks of age about half the inoculated mice were thymectomized, the thymus being sucked out of the thorax through an incision in the neck. The three groups were caged side by side and maintained on ordinary laboratory diet.

The results are given in Table 1. Almost all the inoculated mice which were not thymectomized succumbed to leukæmia between 3 and 6 months of age. The majority of the untreated control mice contracted the disease but not until after the seventh month. None of the mice inoculated with either leukæmic thymus or leukæmic lymph node extracts at birth and afterwards thymectomized has yet succumbed to leukæmia. In contrast to the recent findings of Furth ${ }^{8}$ no tumour other than leukæmia has yet been seen in any mice of the present series.

The results clearly show that in $A k$ mice inoculated at birth with cell-free extracts of leukæmic tissues,
Table 1. Incidench of Leuk amia in aki Mice Injected at Birth WITh FILTRates FROM $A k l$ LeUKamic Tissues

\begin{tabular}{|c|c|c|c|c|c|c|c|c|}
\hline & $\begin{array}{c}\text { Total } \\
\text { Treat- }\end{array}$ & \multicolumn{3}{|c|}{ Age in days at time of diagnosis } & \multicolumn{2}{c|}{$\begin{array}{c}\text { Leukrmia } \\
\text { incidence }\end{array}$} \\
\hline $\begin{array}{c}\text { ment } \\
\text { of } \\
\text { mice }\end{array}$ & $\begin{array}{c}60- \\
90\end{array}$ & $\begin{array}{l}91- \\
150\end{array}$ & $\begin{array}{c}151- \\
180\end{array}$ & $\begin{array}{c}181- \\
210\end{array}$ & $\begin{array}{c}211- \\
300\end{array}$ & No. & $\begin{array}{c}\text { Per } \\
\text { cent }\end{array}$ \\
\hline $\begin{array}{c}\text { Injected } \\
\text { at birth } \\
\text { Injected } \\
\text { at birth, } \\
\text { thym- } \\
\text { ectom- } \\
\text { ized } \\
\text { Control }\end{array}$ & 29 & 1 & 18 & 5 & 2 & 1 & 27 & 93 \\
\hline
\end{tabular}

thymectomy suppressed the subsequent appearance of leukæmia. There can be little doubt as to the cell-free nature of the present extracts of leukæmic tissues for no leukæmia appeared in the thymectomized and inoculated animals, whereas it can easily be shown that thymectomy does not affect the transmission of leukæmia by cell graft. The effect of thymectomy on the incidence of leukæmia in low-leukæmic strain $C 3 H$ mice inoculated at birth with $A k$ leukæmic cell-free extracts is under inves. tigation and will be reported later.

I am indebted to a scholarship from the University of Queensland, Brisbane, Australia, and to Profs. A. Haddow and P. C. Koller and Dr. R. J. C. Harris for their interest. The investigations have been supported by grants to the Chester Beatty Research Institute (Institute of Cancer Research : Royal Cancer Hospital) from the British Empire Cancer Campaign, the Jane Coffin Childs Memorial Fund for Medical Research, the Anna Fuller Fund, and the National Cancer Institute of the National Institutes of Health, U.S. Public Health Service.

Note added in proof. Since this communication was submitted for publication I have learned that similar results have been obtained in $C 3 H f / G s$ mice by Drs. Levinthal, Buffett and Furth, to be published in Proc. Soc. Exp. Biol. and Med.

$$
\text { J. F. A. P. MILler }
$$

Chester Beatty Research Institute,

Institute of Cancer Research,

Royal Cancer Hospital,

Fulham Road,

London, S.W.3.

Jan. 26.

${ }^{1}$ McEndy, D. P., Boon, M. C., and Furth, J., Cancer Res., 4, 337 (1944).

${ }^{2}$ Kaplan, H. S., J. Nat. Cancer Inst., 11, 83 (1950).

${ }^{3}$ Law, L. W., and Miller, J. H., J. Nat. Cancer Inst., 11, 425 (1950).

- Gross, L., Cancer Res., 18, 371 (1958).

- Harris, R. J. C., J. Chron. Dis., 8, 58 (1958).

${ }^{6}$ Rudali, G., Duplan, J. F., and Latarjet, R., Bull. Assoc. franc. pour l'étude Cancer, 44, 440 (1957).

" Furth, J., Buffett, R. R., Banasiewicz-Rodriguez, M., and Upton, A. C., Proc. Soc. Exp. Biol. and Med., 93, 165 (1956).

${ }^{8}$ Buffett, R. F., Commerford, S. L., Furth, J., and Hunter, M. J. Proc. Soc. Exp. Biol. and Med,, 99, 401 (1958).

\section{Plaque Production with Yellow Fever and Related Arthropod-borne Viruses}

WHEN a monolayer of chick fibroblasts is exposed to infection with a suitable dilution of Western Equine Encophalomyelitis virus and afterwards incubated under a layer of agar containing cell nutrients, areas of cell destruction or 'plaques' are produced; these were shown by Dulbecco ${ }^{1}$ to result from infection by single virus particles. The plaque technique has since been applied to a number of other viruses; but 